\title{
The Intellectual Life and Cultural Milieu of Jewish Communities in Medieval Kaffa \\ AND Solkhat \\ Golda Akhiezer
}

\begin{abstract}
This study is an attempt to reconstruct the intellectual life of the Crimean Jewish communities (both Rabbanite and Karaite) from the Middle Ages to early modern times in their wide cultural context. The article is based on manuscripts related to Solkhat, the regional capital of the Golden Horde, and Genoese (and early Ottoman) Kaffa, which can shed light on the spiritual life of their Jewish communities. These manuscripts provide us with a perspective on the areas of interests, patterns of knowledge, and modes of study prevalent in these Jewish communities. They offer evidence for the contents of Jewish libraries and the span of Crimean Jews' intellectual contacts with their Jewish and non-Jewish cultural environments.
\end{abstract}

The event that inspired me to reconstruct Jewish intellectual life in medieval Crimea was an important discovery - a thirteenth-century synagogue in Stary Krym, the medieval Solkhat. Stary Krym, nowadays a second-tier city, served as the Crimean capital to the Golden Horde from the 1260s until the middle of the fourteenth century. ${ }^{1}$ This synagogue was discovered by Mark Kramarovsky, historian and archeologist from the State Hermitage Museum (in St. Petersburg), who started his excavations there in $2015 .^{2}$ According to the preliminary conclusions, the synagogue was located in the most ancient part of the city - the Jewish (Karaite and Rabbanite) quarter. The synagogue could accommodate more than two hundred people, which might indicate that the community numbered as many as a thousand souls. We cannot definitely conclude whether it was a Rabbanite or Karaite synagogue. Its discovery, combined with other Jewish and external

I express my gratitude to my colleagues and friends for their important comments and remarks: Haggai Ben-Shammai, David Cassuto, Ofer Elior, Peter Golden, Alexander Gordin, Mikhail Kizilov, Mark Kramarovsky, Tzvi Langerman, Robert Morisson, Yael Okun, and Olga Vasilieva.

1. The Golden Horde was one of the largest territorial states in Europe and Asia in the Middle Ages. From 1224-66 it was a part of the Mongol Empire; due to its fragmentation it became a separate khanate, known also as the Qıpçaq Khanate or as the Ulus of Juchi. The territories under its rule extended from Danuba to Siberia, and included the Pontic Steppe, the Crimea, north Caucasus, Khorezm, Tabriz, northern Afghanistan, Rus principalities, and Itil Bulgars. In the fifteenth century it disintegrated into several smaller khanates, and the Crimea was one of them.

2. For the preliminary results of the excavations, see Mark Kramarovsky, "Krym (Solkhat): kistorii karaimsko-rabbanitskoi obshchiny v XIII-XIV vv.," in Belgradskii sbornik: Trudy Gosudarstvennogo Errmitazha $k$ XXIII Mezhdunarodnomu kongressu vizantinistov, vyp. 80 (2016) (St. Petersburg: Gosudarstvennyi Ėrmitazh, 2016), 65-84. 


\section{Golda Akhiezer}

sources, can significantly change our perceptions concerning the center and periphery of the Jewish world in the Middle Ages, and the character of Jewish intellectual life and its cultural environment in the Black Sea region.

A number of factors hinder research on Crimean Jewry between the thirteenth and early sixteenth centuries. There is an unfortunate perception of this region as peripheral to the Jewish world. This period is also considered obscure, because existent sources are fragmentary. Therefore, even after the opening of the archives of the former USSR about twenty years ago, ${ }^{3}$ scholars still prefer to deal mostly with the Crimean materials from the eighteenth to twentieth centuries. ${ }^{4}$ In addition, a widespread (but not unique) tendency in the study of Jewish intellectual history is to describe specific aspects, such as defined historical processes, modes of thought, or halakhic practices. In recent decades, scholars have begun to paint a broader picture of the interaction and cultural exchanges between the Jewish and non-Jewish worlds in a wider Jewish and general context, as I will attempt to do here as well. ${ }^{5}$

Early works on Crimean Jewry, which dealt inter alia with the medieval period, still remain, despite their importance, ${ }^{6}$ rather isolated from other Jewish and more general studies (including those on the Byzantine era). Up to the present day, Crimean Jewry has been perceived by many scholars as a marginal phenomenon, whose cultural context is obscure. This attitude derives from

3. The major manuscripts related to Crimean Jewry are preserved in Firkovich's two collections and private archive at the National Library of Russia in St. Petersburg (henceforth RNL), the Institute of Oriental Studies (IOS) in St. Petersburg, and the Harkavy Collection of the National Library of Ukraine.

4. See, for example, Dan D. Y. Shapira and Daniel J. Lasker, eds., Eastern European Karaites in the Last Generations (Jerusalem: Yad Ben-Zvi and Center for Research on the History and Culture of Polish Jews, 2011); Dan Shapira, ed. Mazevot bet he-'almin shel ha-Yehudim ha-Kara'im be-Çufut Qaleh, Krim (Jerusalem: Yad Ben-Zvi, 2007/8); Mikhail Kizilov, Karaites through the Travelers' Eyes: Ethnic History, Traditional Culture and Everyday Life of the Crimean Karaites According to the Descriptions of the Travelers (Simperopol: Al-Qirqisani Center, 2003).

5. For some examples of the last tendency, focusing on text transmission, knowledge, and cultural meaning, see the works of Ofer Elior, Ruah hen yahlof 'al panay: Yehudim, madda' u-kria' 12101896 (Jeruslaem: Yad Ben-Zvi, 2016); Gad Freudenthal, Science in the Medieval Hebrew and Arabic Traditions (Burlington: Ashgate, 2004); Y. Tzvi Langermann and Robert G. Morrison, eds., Texts in Transit in the Medieval Mediterranean (Leiden: Brill, 2016); Moshe Taube, "Transmission of Scientific Texts in $15^{\text {th }}$-Century Eastern Knaan," Aleph 10, no. 2 (2010): 315-53. See also the earlier works that reflect this tendency, such as by Moshe Idel, Kabbalah: New Perspectives (New Haven, CT: Yale University Press, 1988), and David B. Ruderman, Jewish Thought and Scientific Discovery in Early Modern Europe (New Haven, CT: Yale University Press, 1995).

6. See Abraham Harkavy, Altjudische Denkmaler aus der Krim, mitgetheilt von Abraham Firkovisch (1839-1872) und geprüft von Albert Harkavy, Mémoires de l'Académie Imperiale des Sciences de St.-Pétersbourg (St. Petersburg: M. Eggers et Cie., J. Issakof, et J. Glasunof, 1876). Efraim Deinard, Massa' Krim (Warsaw, 1878; repr. Jerusalem: Kedem, 1970/71); I. Berlin, Istoricheskie sud'by evreiskogo naroda na territorii Russkogo gosudarstva (St. Petersburg: Evreiskaia istoricheskaia biblioteka, 1919), 175-200. The author traces the ties between east European and Crimean Jewish communities. See also Simon G. Bernstein "Ha-maḥzor ke-minhag Kaffa, toldotav ve-hitpathuto," in Sefer yovel li-khevod Shmuel Kalman Mirsky, ed. Simon G. Bernstein and Gershon A. Horgin (New York: Va'ad ha-Yovel, 1958), 451-538. 
some specific characteristics of this Jewry, which was a conglomerate of various communities from Muslim and Christian lands. The local non-Jewish environs included the Genoese and Armenian communities, and a variety of little-known ethnic and religious groups belonging to the Golden Horde. In fact, the very notion of a developed culture in the Golden Horde was not obvious, and only in the last decades has this preconception undergone intensive revision in light of archeological and other discoveries. ${ }^{7}$ All these factors demand that researchers possess in-depth knowledge of these environments, and complicate the accepted classification and mapping of Crimean communities in the habitual depiction of Jewish culture and geography. ${ }^{8}$

One of the crucial factors that made the Crimean Peninsula an important center of the Jewish world was its location at a cultural crossroads between Byzantine, Persian, Middle Eastern, Caucasian, Italian, and east European Jewish communities. This center had connections with communities in other parts of the Mongol Empire, though this is poorly documented, as most sources were lost during the Mongol invasion of Central Asia, with the consequent destruction of many Jewish communities and their partial Islamization.

This study is an attempt to provide a perspective on the fields of Jewish intellectual interests and modes of study prevalent in medieval Crimea, primarily in the Solkhat and Kaffa communities, and to reveal the span of their cultural contacts outside the Crimea, based on the analysis of manuscripts and other Jewish and external sources from the fourteenth to the early sixteenth centuries. ${ }^{9}$

\section{Historical and Cultural Background of the Medieval Crimean Communities}

Considerable archeological and literary data attest to a Jewish presence in the Crimea in the Hellenistic and early Byzantine periods. ${ }^{10}$ However, there are no sources from the eleventh to the thirteenth century, and we therefore cannot definitively claim that a continual Jewish presence existed in the Crimea since the Hellenistic period. Jewish settlements appeared in Solkhat and Kaffa in the second half of the thirteenth century.

7. See Mark Kramarovsky, Chelovek srednevekovoi ulitsy: Zolotaia Orda, Vizantiia, Italiia (St. Petersburg: Evraziia, 2012).

8. Jean C. Attias raised a similar problem regarding research on Byzantine Jewry in the Hebrew edition of his book, Ha-perush ke-dia'log: Mordekhai ben Eliezer Comtino, Kushta 1460 (Jerusalem: Magnes, 2007), 3. Since it "did not raise special interest from any ideological point of view and ... it did not provide any pretext for scholars to build a myth of some Golden Age, and since it is located on the periphery of the Jewish world, the Jewish Byzantine intellectual tradition became a victim of common research habits that do not usually go beyond the closed circle of science dealing only with known phenomena."

9. It is not possible to include the archival and other material in its entirety in the article. I am preparing for publication the full survey of the related sources.

10. This period is beyond the scope of this study. See, for example, D. I. Dan'shin, "Fanagoriiskaia obshchina iudeev," Vestnik drevnei Istorii 1 (1993): 59-72; Mikhail Kizilov, La Judée criméenne: Histoire du Judaïsme en Crimée (Simferopol: Dolia, 2016), 23-50. 


\section{Golda Akhiezer}

The city of Solkhat (Solcati [Italian] / Eski Kırım [Tatar] / Старый Крым [Russian]) was founded in the 1260s as a result of the Mongol invasion of the Crimea in the 1230s. Located on the Silk Road, the city became a center of tax collection. It received merchants from close and distant lands, who visited its market and stayed in its caravansaries, some continuing their journey to Middle Asia, Iran, and China. Jews settled in Solkhat before the Golden Horde's adoption of Islam, which was introduced by Khan Uzbek (1312-1242) in the 1320s among the Mongol elites, ${ }^{11}$ and gradually became the prevalent religion. Solkhat reached the peak of its economic and cultural prosperity by the mid-fourteenth century. ${ }^{12}$ A wide variety of ethnic and religious groups could be found in Solkhat: Islamized Mongols; Genoese, Venetians, and other residents of Italian origin; Orthodox Greeks and Slavs; Armenians both Gregorian and Catholic; Nestorians; Qıpçaqs (both Christian and Muslim); Anatolian Seljuks; Tengrists; and Jews. Early Islam in Solkhat had a strong Sufi tendency, since the key figures involved in the spread of this new religion ascribed to various Sufi schools of thought. They visited the Crimea or relocated there in the late thirteenth and early fourteenth century from Iraq, Middle Asia, Anatolia, and elsewhere. ${ }^{13}$ Solkhat had Muslim, Christian, and Jewish quarters, each with their corresponding public structures. During the fourteenth century, Solkhat was one of the major centers producing Armenian books for the Crimean region and Byzantium, although after the end of the century, this role gradually passed to Kaffa. ${ }^{14}$ This economic and cultural environment created favorable conditions for thriving Jewish communities.

11. The first mosque in Solkhat was not built before $1262 / 3$, and a madrasah opened nearby.

12. In 1443, Haji Devlet Giray proclaimed himself the khan of a state independent from the Golden Horde - the Crimean Khanate, and he relocated its capital to Bakhchesaray. This event marked the beginning of a period of gradual decline of Solkhat.

13. The Moroccan traveler Ibn Batuta, who visited the Crimea at the peak of its prosperity (c. 1334) mentioned meeting Abu Bakr ar-Rumi of Anatolia. Abu Bakr, the author of the Kalendarnameh (the commentary on the mystical poem by Jalal-ad-Din Rumi, "Masnawi"), was a Sufi who served as an imam of the biggest mosque in Solkhat. Sufi institutions in Solkhat included abodes for dervishes, Sufi orders, etc. On Ibn Batuta's visit to Solkhat, see Mark Kramarovsky, "Zolotaia Orda: Krym i Dasht-i-qıpçaq v XIII-XIV vekakh," in 'Podarok sozertsaiushchim' - stranstviia ibn Batuty, Anton Pritula i dr. (red.) (St. Petersburg: Izd. Gosudarstvennogo Ėrmitazha, 2015), 300.

14. T. Sargsian, Svod armianskih pamiatnykh zapisei, otnosiashchikhsia k sopredel'nym regionam (XIV-XVvv.) (Simferopol: Sonat, 2010), 23-24. In the fourteenth century, the Catholic Church in the Crimea, which conducted active missionary work among the local population, copied the Gospels for its mission of Solkhat (1338). Notably, the names of the scribes remained Turkic and even Muslim (Amin ad-Din Kutlug-Bei and Diya ad-Din Hwadja b. Maula Naib Nur ad-Din). In 1374, a Nestorian lectionary was also copied in Solkhat. See Kramarovsky, "Zolotaia Orda," 303. As part of their missionary activity, the Franciscans composed (possibly in Solkhat) the Codex Cumanicus (presently housed in the Biblioteca Nazionale Marciana in Venice, Cod. Mar. Lat. DXLIX), a practical handbook of the Cuman language, with glossaries in Italo-Latin, Persian, and Cuman. It also included a collection of religious texts and folkloric materials. Codex Cumanicus is the most important surviving record of the Q1pçaq language, spoken in the period of the Golden Horde by the local Turkic population and later, in Mamluk Egypt, also adopted by Armenians and Karaites. On the text's language and history, see Peter Golden, "The 
Geographically neighboring Kaffa (present-day Feodosia), established by the Genoese in the 1270s, turned into a flourishing seaport by the end of the thirteenth century. ${ }^{15}$ It served as one of the foremost trading transit centers to the ports of Asia Minor, such as Trebizond, Sinope, and, most importantly, Constantinople. Kaffa was an important enclave of Christian Europe in the Muslim world. The second half of the thirteenth century seems to have been a period of Jewish settlement in Kaffa, although evidence for this claim is uncertain, despite two sources that document the construction of a Rabbanite and a Karaite synagogue in Kaffa during this period. ${ }^{16}$

Following the Ottoman conquest (1475), the Genoese were massacred and expelled from Kaffa and from their other coastal cities (Sudak, Balaklava). The Ottomans also conquered the Christian principality of Mangup (Theodoro) in southwestern Crimea. Jewish communities survived in Kaffa, but from the late fifteenth century onwards new Rabbanite and Karaite centers in Karasubazar, Mangup, Çufut-Qaleh, and Gözleve emerged or grew due to migration from Kaffa and Solkhat.

The Solkhat and Kaffa communities were culturally unique in the Jewish world, but were shaped by the same historical and cultural processes as those in Byzantium. For centuries, prominent Byzantine Rabbanite and Karaite scholars, such as Mordekhai Comtino, Hanokh Zipporta, Eliyahu Bashyachi, and Caleb Afendopolo, engaged in legal and exegetical polemics and competed with each other for scholarly primacy while studying mathematics, astronomy, Kabbalah, and philosophy from each other, and even together. ${ }^{17}$ The few surviving sources reveal that such cultural exchanges also existed on a smaller scale between Rabbanite and Karaite communities in the Crimea.

From the end of the fifteenth century, the mass migration of exiles from Spain and Portugal to the Ottoman Empire resulted in a Jewish cultural paradigm shift, and in the gradual decline and assimilation of the Romaniots into the Sephardic cultural milieu. As a result of the Sephardic cultural impact, Byzantine Karaites underwent a cultural transformation, which was expressed, inter alia, in the

Codex Cumanicus," in Central Asian Monuments, Beylerbeyi, ed. Hasan B. Paksoy (Istanbul: Isis Press, 1992), 33-63.

15. We have almost no data on the Jewish presence in other Genoese coastal cities. Evidence of the Jews in Sudak (Soldaia [Italian]) appears in a colophon by the Armenian chronicler, Carapet (1365). He depicts the Genoese massacres, in which they brutally murdered the Muslim and Jewish populations of Sudak and confiscated their property. It was an act of revenge against the Solkhat ruler, Janibek, for his murder of Christians. See Sargsian, Svod armianskih pamiatnykh zapisei, 156-57.

16. Vasilii Kondaraki mentioned an inscription on one of the surviving beams of the Kaffian Karaite synagogue with the date of its construction-5052 (1292). See Vasilii Kondaraki, Universal'noe opisanie Kryma (St. Petersburg, 1875), pt. 15, c. 133. David ben Eliezer Lekhno (d. 1735), the leader of Karasubazar Rabbanite community in the eighteenth century, mentions in his introduction to the Mahzor Kaffa that the Rabbanite synagogue was built in 1309. See Deinard, Massa' Krim, 148. His source is unknown.

17. For studies of Karaite disciples under the guidance of Rabbanite scholars, see Attias, Ha-perush ke-dia'log, 32-34; 55-65. 


\title{
Golda Akhiezer
}

adoption of new literary genres, new fields of knowledge, and an increasing interest in their own history as well as that of non-Jews. ${ }^{18}$ All these changes did not bypass the Crimean communities.

\section{Jewish Settlement in Solkhat and Kaffa}

The date of the appearance of Jewish communities in Solkhat is quite obscure. The earliest evidence comes from the Byzantine Karaite scholar Aaron ben Joseph the Physician (c. 1250-1320), who mentions in his Sefer ha-mivhar a Karaite-Rabbanite calendar dispute in Solkhat in 1278, the early stage of the Jewish presence in this city. ${ }^{19}$ Unfortunately, he does not provide any details on these communities. Solkhat, which was seemingly built from nothing in the 1260 s and rapidly developed into a regional capital, may have received Jewish immigrants from other parts of the Mongol Empire-Persia or Middle Asia. In favor of this hypothesis, we have the words of David ben Eliezer Lekhno (d. 1735), the leader of Karasubazar Rabbanite community in the eighteenth century, in his introduction to Mahzor Kaffa, called Hazzaniyah:

\begin{abstract}
Our ancestors lived predominantly in Kaffa and in the city of Kirim, called Solkhat. They came there on foot directly from Babylonia and Persia due to the exasperation of the oppressor who planned to destroy, and succeed in doing it: David ben Zakkai the Prince [הנשיא], the head of Diaspora, was killed by the Ishmailite king Abbas; ${ }^{20}$ later occurred the event with David el David who claimed himself Messiah. ${ }^{21}$
\end{abstract}

Lekhno linked Jewish immigration to the Crimea to the persecutions of Babylonian Jewry, including the rebellion of David Alroy in the twelfth century. Lekhno's source is unclear; it could be an oral tradition with some historical core, possibly connected to later Jewish immigration. As we will see, Jews indeed arrived in the Crimea from Persia. They may have also emigrated from Byzantium to Solkhat. A similar process took place in non-Jewish communities: the Seljuk population of Solkhat came from Anatolia, ${ }^{22}$ while the massive

18. Golda Akhiezer, Historical Consciousness, Haskalah, and Nationalism among the Karaites of Eastern Europe (Leiden: Brill, 2018), 45-49.

19. Aaron ben Joseph, Sefer ha-mivhar (Gözleve, 1835), 14b. The opinion, widespread among scholars, that Aaron ben Joseph was born in Solkhat, is unjustified. Neither this passage nor other sources support this claim. Moreover, he was born before the establishment of Solkhat and his mother tongue was Greek (he used Greek words in his writings). In addition, the Karaite author, Mordekhai ben Nissan, claimed that he originated from Constantinople: Mordekhai ben Nissan, Dod Mordekhai (Vienna: 1830; repr. Ramle: 1965/66), 71.

20. Lekhno was mistaken: this was a great grandchild of David ben Zakkai, Hizkiyah ben Judah, who was executed by the caliph in 1040. It happened more than two hundred years before the Jews settled in Solkhat and Kaffa.

21. Deinard, Massa' Krim, 148

22. On Anatolian Seljuks and the impact of their cultural tradition, see Mark Kramarovsky, "Krym i seldzhukskii Rum. Solkhat-Krym, kak mediator anatoliisko-islamskogo vektora v culture poluostrova," in Pritula, 'Podarok sozertsaiushchim,' 284-89. 
Armenian settlement in Solkhat and Kaffa in this period consisted of emigrants from the area of historical Armenia and from the sphere of Byzantine and Persian influence. ${ }^{23}$ Notably, long before the fall of Constantinople, the culture of those parts of the former Byzantine Empire under Ottoman rule was strongly influenced by Persia. This influence was also felt among Jews in the early Ottoman period. One of the striking examples of such a cultural imprint was the philosopher and physician Elisha ha-Yevani (the Greek), whose works were known in the Crimea.

The antiquity of the Karaite community in Solkhat is reflected in a number of Karaite oral traditions (some of which were recorded and elaborated on by Karaite leaders in eastern Europe during the nineteenth century). According to these traditions, (1) Solkhat was the most ancient Karaite settlement in the Crimea during the Middle Ages; (2) Karaites arrived in Solkhat together with the Tatars ${ }^{24}$ and (3) Karaites were brought from Solkhat to Lithuania (and later to Poland) by the Lithuanian dukes. ${ }^{25}$

As Dan Shapira and I have suggested in an article on the beginnings of Karaism in eastern Europe, the fact that both the Karaites and Armenians in eastern Europe spoke the same dialect of Turkic language, Q1pçaq, which was common in the Golden Horde and Mamluk Egypt,${ }^{26}$ may indicate that both communities possibly arrived in Lithuania and Poland from different regions of the Golden Horde, in particular from one of its capitals, Sarai Berke on the Volga and/or possibly Tabriz. ${ }^{27}$ However, no document supports the claim about the

23. This immigration started following the Mongol invasion in the $1230-40 \mathrm{~s}$, and reached its peak during the fourteenth century. See Anatoly Yakobson, "Armianskaia srednevekovaia arkhitektura v Krymu," Vizantiiskii Vremennik 8, no. 33 (1956): 168.

24. See, for example, evidence from 1833 from Russian historian Piotr I. Keppen, who mentions an oral tradition of the Crimean Karaites that his informants received from their fathers. According to him, the Karaites relocated to the Crimea together with the Tatars, Bukharans, and Circassians. Piotr I. Keppen, Krymskii sbornik: O drevnostiakh Iuzhnogo berega Kryma i gor Tavricheskikh (St. Petersburg, 1837), 290.

Concerning the early residence of the Karaites in Solkhat, the Karaite leader from Evpatoriya in the eighteenth century, Benjamin Duvan, attested to the existence of a Karaite settlement there about five hundred years earlier. See Yona Gurland, Ginze Yisra'el be-St. Petersburg, vol. 1 (St. Petersburg: 1865), 45.

25. See the writings of the east European Karaite leader, Mordekhai Sułtanski, Zekher zaddikim, ed. Samuel Poznański (Warsaw: Hazfirah, 1920), 108-9. According to his anachronistic text, in 1218 "the Great Duke of ... Lithuania, called Witold Jagiełło ... in going to war against the Tartars in the kingdom of Crimea and in defeating them, set upon Crimea and took much booty and a great captivity ... and carried off some Karaites who were in Solkhat ... and brought them to his land, to Lithuania."

26. On the origins and germination of this language, see Yaroslav Dashkevych, "ArmianoQypchiakskii iazyk XV-XVII vv. v osveshchenii sovremennikov,” Voprosy Iazykoznaniia 5 (1981): 87-89; Dan Shapira, "The Turkic Languages and Literatures of the Eastern European Karaites," in Karaite Judaism: A Guide to Its History and Literary Sources, ed. Meira Polliack (Leiden: Brill, 2003), 657-707.

27. Golda Akhiezer and Dan Shapira, "Kara'im be-Lita' u-be-Wołyń-Galicia 'ad ha-me’ah ha-shemoneh 'esreh," Péamim 89 (2002): 34-35. 


\section{Golda Akhiezer}

presence of Jews and/or Karaites in Sarai Berke (unlike the Armenians), ${ }^{28}$ nor their Tabrizian origins (although theoretically these hypotheses are not impossible). An alternative suggestion could be that the early Karaite and Armenian immigrants to eastern Europe came from Solkhat. ${ }^{29}$ This hypothesis, in addition to the Karaite oral traditions on Solkhat, could be supported by the fact that Armenian books written and copied in Solkhat were found later in Galicia and Podolia. ${ }^{30}$ Karaite sources seem to have travelled by the same itinerary: a manuscript of the book Midrash ha-hokhmah, from Solkhat, includes three sale contracts (שטרי מכר) signed on its pages; the latest contract was signed in Lithuania (Troki) in 1598, ${ }^{31}$ where the manuscript was apparently brought by Karaite immigrants from Solkhat.

Texts in the Turkic-Qıpçaq language did not appear in eastern Europe before the sixteenth century. ${ }^{32}$ The same can be said about the Karaite texts. ${ }^{33}$ Notably, both communities started using Turkic-Qıpçaq as a written literary language in eastern Europe, but not in the Crimea, where it served only as a spoken one. Given these factors, we can conclude that the Karaites and Armenians gradually adopted this language in Solkhat and its vicinity before the fourteenth century. ${ }^{34}$ Their first waves of immigration (as early as the end of the fourteenth century), which originated in Solkhat, brought this language to eastern Europe. After the collapse of the Golden Horde and the development of the Tatar language in the Crimea, the remaining communities adjusted themselves to these changes, while their brethren in eastern Europe preserved Turkic-Qıpçaq as either a spoken or a written language. For this reason, the Crimean and east European Karaites could not understand one another in modern times.

Did Karaites and Rabbanites arrive in Solkhat from the same land(s) and at the same time? Were the Karaites of Kaffa from the same origin as their brethren of Solkhat, or did they come from the same regions as the Rabbanite population? At this stage we can only partially answer these questions.

28. For Armenian settlements from the Middle Ages to modern times, see Edmond Schütz, "The Stages of Armenian Settlements in the Crimea," Transcaucasica 2 (1980): 116-35.

29. Schütz suggested that the early Armenian settlement in Lvov and Kamieniec Podolski was from Solkhat. See "Stages of Armenian Settlements in the Crimea," 124.

30. According to an Armenian colophon (1394), Sinan Kotlubei, of Crimean origin, donated a book (lectionary), compiled in Solkhat in 1349, to the Armenian church of Kamieniec Podolski. See Sargsian, Svod armianskih pamiatnykh zapisei, 198-99.

31. Oxford, Bodleian Library MS Mich. 551, 210a. See below for more on this book and its manuscript from Solkhat.

32. Yaroslav Dashkevych, "Kto oni - armiano-qypchiaki?," Banber Matenadarani 16 (1994): 86-88, and Érvand Sevortian, ed., Dokumenty na polovetskom iazyke XVI v. (Moscow: Nauka, 1967).

33. Among the earliest Karaite texts in this language, we find a number of piyyutim from sixteenth-century Troki by the Karaite scholar R. Isaac ben Abraham the Physician. See, for instance, MS Kahana I, no. 121; see Mikhail Kizilov, "Two Piyyutim and a Rhetorical Essay in the Northern (Troki) Dialect of the Karaim Language by Isaac ben Abraham Troki," Judaica 1, no. 2 (2007): 64-75.

34. See Yaroslav Dashkevych, "Kto oni - armiano-qypchiaki?," 83. I am very grateful to Peter Golden for sharing important remarks on this issue. 


\section{The Available Sources and Possible Reconstruction of Intellectual Jewish Life in Medieval CRimea}

In spite of the thirteenth-century testimony of Aaron ben Joseph on the Jewish presence in Solkhat, the existence of a great synagogue there, and the evidence for a Kaffian synagogue during the same century, the earliest available Jewish manuscripts appear only in the fourteenth century. A considerable number of Crimean Rabbanite documents became part of the First Collection of Abraham Firkovich, a Karaite leader and manuscript collector of the nineteenth century, after he confiscated the contents of the ancient genizot in the Krymchak (Crimean Rabbanite) ${ }^{35}$ synagogues and study halls of Kaffa and Karasubazar. ${ }^{36}$ A major portion of these materials were brought by Rabbanites from Kaffa following their relocation to Karasubazar.

Regrettably, the genizah of Kaffa, with its ancient and diverse manuscripts from the communities of Babylonia, Caucasus, Byzantium, Spain, Portugal, Italy, Kievian Rus, Poland, and elsewhere, was lost as a result of the synagogue's destruction during Nazi bombardments. Only a few materials that were previously preserved survived. Some are fragments of the Pentateuch with Babylonian vocalization, which, thus, could be dated to the early Middle Ages. ${ }^{37}$ A large collection of the Rabbanite Krymchak documents that belonged to the Krymchak manuscript collector Lev Kaya, who planned to transfer them to the Ben-Zvi Institute for the Study of Jewish Communities in the East in Jerusalem, was stolen from him in the 1980s. For these reasons, and following the almost total annihilation of the Krymchak community by the Nazis, most of the Crimean Rabbanite manuscripts were irrevocably lost. The Karaite manuscripts, on the other hand, owing to Firkovich's collecting activities, endured a better fate.

The earliest manuscripts that I will address below were brought to Solkhat and Kaffa from other lands as early as the thirteenth or fourteenth centuries, or were created and copied by the Crimean Rabbanites and Karaites. They include legal, exegetical, grammatical, philosophical, mystical, and other texts. ${ }^{38}$ Some of these manuscripts later belonged to community members of Çufut-Qaleh, Mangup, Gözleve, and Karasubazar, who (themselves or their forefathers) had resettled in these places from Kaffa or Solkhat. The origins and dates of these

35. The term "Krymchak" to refer to the Crimean Rabbanites appears in the mid-nineteenth century and gradually comes into use, both by the authorities and by the Jews themselves.

36. See his own description of this fact: Abraham Firkovich, 'Avne zikaron (Vilna: 1872), $15-17,22-24$.

37. See, for example, EVR I BIBL 133, haftarot.

38. As emphasized above, Jewish literary activity in these two cities developed with the backdrop of copying, compiling, and composing books in other communities. For example, the Armenian community possessed and produced books written by Armenian authors, in addition to the Scriptures, exegesis, and homiletics, such as guides on grammar, versification, rhetoric, historical chronicles, and philosophical texts. From non-Armenian authors, they learned of the works of Aristotle, Porphyry, Cyril of Alexandria, Dionysius the Areopagite, Albertus Magnus, Bonaventure, and many others. See Sargsian, Svod armianskih pamiatnykh zapisei, 15-16. 


\section{Golda Akhiezer}

texts can be defined by their colophons, sale contracts, or owner records, which also provide data about their authors, copyists, buyers, and more.

Other types of documents from the thirteenth to fourteenth centuries, such as marriage contracts (ketubot), property sale deeds, and private or other correspondence, were not preserved. For this reason, the economic and social life of Jewish communities in Kaffa and Solkhat can only be partially reconstructed, primarily on the basis of later Jewish documents (from the late fifteenth century onwards) or external sources. ${ }^{39}$

There are a number of colophons on the Torah scrolls in Firkovich's collection related to Solkhat and Kaffa. Research indicates that all of these colophons from the thirteenth century and earlier were forged by Abraham Firkovich. ${ }^{40}$ After his "corrections," the original dates in many cases became unreadable, hence I have not used these materials. In addition, there are some colophons related to Kaffa, which Firkovich made appear a hundred years older.

One such example is a fourteenth-century manuscript, a commentary by Ibn Ezra on the Torah (Exodus, Leviticus, and Chronicles), copied by a member of the Kaffian community, Shlomo ben Jacob, but, according to its colophon, dated from 1281. ${ }^{41}$ The earliest manuscript from Solkhat is a copy of the Midrash ha-hokhmah, ${ }^{42}$ which contains three sale contracts, two from the fourteenth century. The book itself was written in Arabic by Judah ben Shlomo ibn Matka of Toledo around 1247, who translated it afterwards into Hebrew. This was in fact the first Jewish encyclopedia of scientific and philosophical knowledge, which provides a survey of Aristotelian natural philosophy and metaphysics and their interpretation by Ibn Rushd, and also contains material on Euclidian geometry, astronomy, astrology, alchemy, and the mystical meanings of the Hebrew

39. For some data on demography and economic activity of Jews in Kaffa, see Balard Michel, Genes et L'Outre-Mer., T. I: Les actes de Caffa du notaire Lamberto di Sambuceto 1289-1290 (Paris: Mouton, 1973); Veinstein Gilles, "La population du sud de la Crimee au début de la domination ottoman," in Mémorial Ömer Lûtfi Barkan, ed. Robert Mantran (Paris: Maisonneuve, 1980), 227-49. See also the list of the names of Jewish community of Kaffa, in Kizilov, La Judée criméenne, 253.

40. Dan Shapira, "Nyneshnee sostoianie pripisok rukopisei Pervoi kolektsii Firkovicha," Proceedings of the $11^{\text {th }}$ International Conference on Jewish Studies, pt. 1 (Moscow: Sefer, 2004), 102-30. Firkovich possibly intended to prove that the Karaite community of Kaffa was more ancient than the Rabbanite one.

41. RNL Evr I, 23, 190b. The original date is unclear after Firkovich "corrected" it to 1281 (למניננו חמשת אלפים ומ"א) when instead of 100 (and something?) he wrote 41. The Codicological DataBase of Hebrew Paleography Project (The Israel Academy of Sciences and Humanities) suggested the year 1359, which fits Sunday the 3rd of the second month of Adar, as was written in this colophon. I am grateful to Dr. Alexander Gordin, who drew my attention to this fact. The date 1359 is, however, uncertain, even though the watermarks on the manuscript's paper and the combination of paper with parchment were common in Europe (Italy) in the second half of the fourteenth century. In this manuscript, there is no indication that it was copied by a Karaite scribe. The use of the term le-minyanenu was common in Spanish and Italian communities.

42. Oxford, Bodleian Library MS Mich. 551. 
letters. ${ }^{43}$ This treatise was transmitted from Spain to the Italian and Byzantine communities, ${ }^{44}$ and, as we can see, circulated in the Crimea as well.

The manuscript's first signed sale contract (1330) was between Shulamit bat Shemariyah and her daughter-in-law, Malkah. ${ }^{45}$ Shulamit purchased this book from Malkah, the widow of one Abraham ben Shemariyah, to whom it belonged, and paid her 120 coins. It was a deal between two women, with Shulamit buying Midrash ha-hokhmah for undisclosed purposes, maybe to study it herself. There is no indication if these individuals were Karaites or Rabbanites, and the place of the transaction is not mentioned.

Another sale contract signed in the same manuscript (211b), dated to 1389, mentions the Solkhat community (קהל קירים). Unfortunately, it is in poor condition and almost unreadable. The third aforementioned sale contract was signed in sixteenth-century Troki; the book was supposedly transported from Solkhat to Lithuania by the new settlers.

The colophon of another manuscript from Solkhat, the book of Deuteronomy, is a Karaite one (1390). ${ }^{46}$ According to the colophon, the book was dedicated to the Solkhat Great Synagogue by Eliyahu ben Zadok ha-Kohen in the name of his mother, Malkah bat Moses. It was written by the scribe [Judah] ben Eliyahu of Adrianople; the scribe's name could indicate a number of possible situations: either both the scribe and the dedicator were from Adrianople and moved to Solkhat, or the dedicator visited or relocated to Solkhat, ordering this copy from an Adrianopolian scribe before his trip. In any case, this document implies connections between the Karaite communities of Solkhat and Adrianople, an important Karaite cultural center in the fourteenth century.

There are a number of manuscripts of Karaite Byzantine books copied in Solkhat dating from the fourteenth to eighteenth centuries, such as a classic book on Karaite law by Aaron ben Eliyahu of Nicomedia (1328-69), Gan 'eden.$^{47}$ This copy can be dated to the period between the fourteenth and sixteenth centuries, according to its Byzantine script. It includes two ownership notes in different handwritings, both claiming that it belongs to the "holy community of Solkhat." 48

A number of Rabbanite and Karaite texts, according to their colophons, were copied by scribes originated from Solkhat, who relocated to other Crimean

43. Colette Sirat, A History of Jewish Philosophy in the Middle Ages (Cambridge: Cambridge University Press, 1985), 250-55; Steven Harvey, ed., The Medieval Hebrew Encyclopedias of Science and Philosophy (Dordrecht: Kluwer Academic Publishers, 2000), index, s. v. "Judah ben Solomon ha-Cohen."

44. See, for example, the first part of the book, which was copied in Italy, Palatina Library, Parma Italy Cod. Parm. 3023, 99b-145a, the fourteenth century; fragments of this book were copied in the fourteenth century in Thessalonica, Leipzig, Universitaetsbibliothek B.H. fol. 13, 26a-49b; see its fragment from Candia from the same century, Leiden, Universiteitsbibliotheek Cod. Or. 4751, $20 \mathrm{a}-35 \mathrm{a}$.

45. Oxford, Bodleian Library MS Mich. 551, $210 \mathrm{~b}$.

46. New York, Columbia University X 893, B 4776.

47. IOS C 142.

48. See IOS C 142, fol. 112a, $112 \mathrm{~b}$. 


\section{Golda Akhiezer}

Karaite communities, such as Çufut-Qaleh, Mangup, and Kaffa. ${ }^{49}$ The earliest and perhaps only known example of an original exegetical work from Solkhat is Sefat ha-'emet, penned by the Rabbanite scholar Abraham Kirimi/Kırımi. We know from the memorial (yizkor) book of the Kaffa community that Abraham Kirimi was renowned there as the greatest sage after Maimonides and Ibn Ezra. ${ }^{50} \mathrm{His}$ son-in-law, R. Elyakim, was one of the scholars of Kaffa, whose piyyutim were included in the Kaffa Rite, and even in the Karaite siddur in the Crimea. The book by Kirimi, written in 1358, is a commentary on the Pentateuch. ${ }^{51}$ According to his foreword and introductory poem, the author composed it at the request of his Karaite student Hizkiyah ben Elhanan, a scion of a Karaite scholar named Gedalyah (1a-1b). Kirimi called his student a like-minded person (ניאים (מיד דעים), an intellectual (מלא דעים), a Karaite prince (נשיא קראים), and head of officials and aristocrats (ראש סגנים הוא וראש שועים). According to these commendations, Hizkiyah was apparently a Karaite community leader of Solkhat.

That a learned Karaite community leader was a student of the greatest Crimean scholar may be evidence for a flourishing culture of Torah study in Jewish Solkhat and Kaffa of this period, mirroring the contemporary Muslim and Christian societies of these cities. Kirimi's book, Sefat ha-'emet, which has never been systematically researched, ${ }^{52}$ reflects a rationalistic tendency quite common in Byzantine Jewish scholarship of this period, with a strong focus on linguistic, and also philosophic, textual commentary. Among the sources employed by the author, both directly or obliquely, we find Maimonides's Guide of the Perplexed and Sefer ha-madda', Rashi, Shemariyah Ikrity, Ibn Ezra, the grammarian Judah Hayyuj, Sefer melamed ha-talmidim by R. Jacob ben Aba Mari Anatoli, ${ }^{53}$ The Book of Stones, ${ }^{54}$ Midrash ha-hokhmah, and more. It is quite possible that the aforementioned copy of Midrash ha-hokhmah from Solkhat formerly belonged to Abraham Kirimi, or was copied from his own original edition by his disciples.

Among the early manuscripts from Kaffa we find at least six texts copied by the Karaite scribe Hizkiyah ha-Levi, from 1360-76. The earliest one (1360) contains fragments from the Pentateuch. According to his colophon, Hizkiyah copied

49. For instance, the book Ha-mivhar, a commentary on the Pentateuch by Eliyahu ben Joseph (c. 1260-1320), was copied in 1622 by a scribe from Solkhat, who mentioned in his colophon that he finished his work in Çufut-Qaleh, but that his fatherland was Solkhat. See IOS C 37, 154b.

50. Bernstein, "Ha-mahzor ke-minhag Kaffa, toldotav ve-hitpathuto," 455-6.

51. Oxford, Bodleian Library MS Opp. Add. fol. 45, copied in the seventeenth century. See its other manuscripts (both were copied in the eighteenth century): RNL EVR I 50 and IOS D 54. None of these manuscripts are autographed, and it is unclear if their Crimean script belongs to Rabbanite or Karaite scribes.

52. On Kirimi, see Bernstein, "Ha-mahzor ke-minhag Kaffa, toldotav ve-hitpathuto," 465; Sergei Tsinberg, "Avraam Krymskii i Moisei Kievski," Evreiskaia Starina 11 (1924): 97-101.

53. The author, who wrote this treatise in the middle of the thirteenth century, aimed to encourage readers to study philosophy and sciences.

54. The anonymous treatise on minerals, their characteristics and magical traits, is attributed to Aristotle. 
them in Solkhat. ${ }^{55} \mathrm{He}$ was a native of this city before his relocation to Kaffa, where he copied the other texts. One of them, which he copied in 1376, was the Hebrew grammar Sefer ha-shorashim by David Kimhi (1160-1235). ${ }^{56}$ A later ownership note, dated 1393, possibly after Hizkiyah's death, appears on this book, probably made by his son Moses ben Hizkiyah ha-Levi of Kaffa (247b). Hizkiyah also copied the Sefer ha-mivhar, written by Aaron ben Joseph. ${ }^{57}$ A sale contract (dated 1484) in this book indicates that it was sold in Istanbul by a certain Isaac ha-Zarzur to the Karaite scholar, Caleb Afendopolo, and was signed by a witness named Sabbatai ben Mordekhai Bashyachi (129a). The Karaite community from Adrianople also lived at this time in Istanbul, having been forced to move there following a sürgün that began in $1455 .{ }^{58}$ It is unclear under what circumstances Hizkiyah's copy of this book arrived in Istanbul. Quite possibly, in this period, these settlers, having lost part of their literary patrimony during the relocation, still had a voracious need for books ${ }^{59}$ and received a supply from more stable Jewish population centers.

One of the collections of texts from Kaffa contains a copy of fragments from Lekah tov, a midrashic commentary on the Pentateuch and the Five Megillot by the Byzantine scholar R. Tobias ben Eliezer of Kastoria (born c. 1090). ${ }^{60}$ This collection also contains the exegetical book of the Byzantine Karaite author Jacob ben Reuven $\left(11^{\text {th }}-12^{\text {th }}\right.$ centuries), Sefer ha-'osher (3b-308a), and a vocabulary of Aramaic words (399a-311a). ${ }^{61}$

A collection of miscellaneous texts from Kaffa, the latest dating from the seventeenth century, contains astronomical fragments and calculations, as well as quotes from Ptolemy, al-Battani, and Mordekhai Comtino. ${ }^{62}$ There is also an astrological text dealing with the names of angels associated with the days of the week and the planets (67a-72a). Rashi's commentary on Proverbs (1a-33a)

55. RNL EVR I, A 6.

56. See its colophon, RNL EVR I, 78, 246b.

57. Oxford, Bodleian Library MS Opp. Add. Qu. 46.

58. The Turkish word sürgün means "expulsion" or "deportation." See Joseph R. Hacker, "Shitat ha-sürgün ve-hashpa'atah 'al ha-ḥevrah ha-yehudit ba-'imperyah ha-'othmanit ba-me'ot ha-hamesh 'esreh 'ad ha-sheva' 'esreh," Zion 55 (1990): 27-82.

59. Eliyahu Bashyachi (c. 1420-90) bewailed that he failed to find any Karaite books on the schism between Karaites and Rabbanites. See Eliyahu Bashyachi, 'Adderet Eliyahu, with a foreword by Zvi Ankori (Ramle: National Council of Karaite Jews in Israel, 1965-6), the beginning of the unpaginated introduction. Bashyachi's contemporary, Shabbtai Provato, mentioned that there was a shortage of Karaite books in this period. See Jacob Mann, Texts and Studies in Jewish History and Literature, vol. 2 (Cincinnati, OH: Hebrew Union College Press, 1935), 299 n. 11. They both wrote after the sürgün, possibly the cause of the loss of these books. Another, and earlier, factor could be the great conflagration in Adrianople of March 1446, during the Janissary rebellion, when the market and central part of the city were consumed by flames.

60. Leiden, Universiteitsbibliotheek, Or. 4769, 165b, 312a-329b.

61. Lekah tov and a part of Sefer ha-'osher were copied by the same scribe, Hizkiyah ha-Levi. See his colophon in Leiden, Universiteitsbibliotheek, Or. 4769, $165 \mathrm{~b}$.

62. IOS B 356, 32a-44b. The author does not refer to Comtino's specific works. 


\section{Golda Akhiezer}

and a fragment of Midrash Mishle 31:14 ${ }^{63}$ (32a-33a) were copied by someone named Moses of Kaffa. The date of 1382 in the scribe's colophon (33a) was possibly changed by Firkovich from $1482 .{ }^{64}$

An interesting fact is revealed by a copy of the Karaite Sefer ha-mizvot (i.e., Gan 'eden, by Eliyah from Nicomedia) with a colophon dated to $1424 .{ }^{65}$ The scribe was Adoniyah ben Elya Kirici from the community of Eboli (southern Italy). Adoniyah copied this book for Israel of Kaffa. It is unclear whether the copyist lived in Italy and copied this book for his client from Kaffa. In any case, we can trace a link between the Kaffian and Eboli communities. Was Kirici a Karaite and was there a Karaite community, or some Karaite presence, in Eboli in the fifteenth century? Or was he an Italian Rabbanite scribe who also accepted commissions from Karaite clients? Both possibilities are quite surprising.

Another case represents a clear indication of a Rabbanite scribe copying a book for a Karaite client, but in this instance the book was not Karaite in origin. According to the colophon, ${ }^{66}$ in 1487 Isaac ben Moses, the Orphan of Candia, copied an astronomical book in Istanbul for Judah, a Karaite from Kaffa. It is a Hebrew translation of the treatise On the Configuration of the World (Fi hay'at al-'alam) by the Muslim scholar Ibn al-Haytham (964-1040), who composed about two hundred works on optics, mathematics, philosophy, astronomy, and more. ${ }^{67}$ The book was translated by Jacob ben Makhir ibn Tibbon, called also Don Profiat (c. 1236-1305), a physician and astronomer from Provence ${ }^{68}$ The Rabbanite scribe wished for his Karaite client: "God will award him, his descendants, and descendants of his descendants to understand it [= this book] and to meditate therein."

Another copy of the Karaite book Gan 'eden ${ }^{69}$ belonged to Elya ha-Kohen of Çufut-Qaleh. It was copied by three scribes, one of whom lived in Istanbul. He recorded that he copied twenty-five pages of this book in 1459, and that his name was "Joseph ibn Hayim the son of Sa adyah ibn Hayim ... from Agroponti [Negroponte ${ }^{70}$ ]" and that he "wrote it for R. Elya the son of honorable Rav Michael" (260a). The scribe was a Karaite: he referred in the colophon to the author of the book, Aaron of Nicomedia, as "our teacher." Can this colophon testify to a Karaite presence in Negroponte in the fifteenth century? Theoretically, it is quite possible, but we have no documents to support this premise.

63. Babylonian anonymous commentary on Proverbs composed not before the ninth century. Published for the first time in Istanbul in 1512. See RNL EVR I, 17, 32a-33a.

64. Firkovich possibly turned the letter resh to kof. Since this opinion of the Codicological Data-Base of Hebrew Paleography Project is based only on the fact that the leg of the letter kof in the date is thinner than in other places in the text, the reality of the forgery here is uncertain.

65. RNL EVR I, 630, 9b.

66. RNL EVR I, 354.

67. Y. T. Langermann, Ibn al-Haytham's On the Configuration of the World (New York: Garland, 1990). On its manuscripts and Hebrew translations see pp. 34-40.

68. Ibid., 37-38.

69. NLI B $151\left(8^{\circ} 1052\right)$.

70. Chalkis, the chief town of the island of Euboea, in Greece. 
An active figure in the intellectual life of both Solkhat and Kaffa seems to have been a Karaite named Joshua ben Nahamu Kirimi. He lived in the late fifteenth to early sixteenth centuries, and relocated from Solkhat to Kaffa. ${ }^{71}$ Joshua copied some fragments from Karaite books by Eliyahu Bashyachi and Caleb Afendopolo, and explained his purpose in an emotional colophon (1502), full of criticism of his coreligionists in Kaffa. He decided to copy these fragments because he was worried that

[the local Karaites] leave our Torah .... and are exerting themselves only with money, silver and gold, and pursuit the fulfillment of their desires - food and drink ... thus I decided to disseminate the Torah among them [inserted from the left side: and among all communities of Israel, among communities of Yeshurun]. ${ }^{72}$ I lift up my eyes to You, to You who sit enthroned on heaven [Ps. 123]" (8a).

Joshua ben Nahamu's manuscripts include other texts, both copies and original compositions. ${ }^{73}$ The latter include a treatise on ritual slaughter (32b-35a) and a text dealing with biblical chronology, which calculates the intervals between various events such as Creation, the Deluge, the Exodus from Egypt, and more (35b-36a). He further mentions the Hasmonean and Roman periods, and concludes with Muhammad's escape from Mecca to Medina. This collection contains sermons by David ibn Elazar ibn Pakuda, a fragment of a piyyut by Ibn Gabirol, "Amun yom zeh," and the tractate Milot ha-higayon by Maimonides. ${ }^{74}$ In 1504, Joshua ben Nahamu also copied the treatise 'Eshkol ha-kofer (A cluster of henna) by the Byzantine Karaite scholar of the twelfth century Judah Hadassi. He mentioned this fact in his colophon on the manuscript of the commentaries of Ibn Ezra on the Pentateuch, which was in his possession but copied by another hand. ${ }^{75}$ However, this manuscript of 'Eshkol ha-kofer is itself missing.

The last mention of Joshua ben Nahamu we find is in a sale contract (1548) in one of the texts of the miscellaneous Rabbanite collection in possession of a Karaite: ${ }^{76}$

This precious book is The Guide of the Perplexed by our teacher Gaon, honorable R. Moses the son of honorable Rav Maimon ... in holy community of Kirker [Çufut-Qaleh], may its Rock keep and safeguard it, that we bought it from Baba the son of honorable Rav Raphael of blessed memory, the son of honorable Rav Joshua ben Nahamu of blessed memory ... and a buyer was Moses the son of Rav Elya of blessed memory ... 1548.

71. RNL EVR I, 635. Firkovich forwarded these texts with the following words: "Here are the words of Joshua ben Rav Nahamu Kirimi of blessed memory in the city of Solkhat" (1a).

72. He probably means all the communities, including the Rabbanite ones.

73. See IOS B 58. This collection was apparently completed by Moses ben Zadok. Moses ben Zadok inserts his own liturgical poem, see ibid., 79a. Joshua refers a number of times in his texts to a certain R. Moses, stating that he was his son-in-law. Therefore, the owner was possibly the same person.

74. Ibid., 144b-163b. The last text was possibly copied by Moses ben Zadok.

75. RNL EVR I, 26. See colophon, 253a. See Ibn Ezra, ibid.,1a-252b.

76. RNL EVR I, 479, $1 \mathrm{~b}$. 


\section{Golda Akhiezer}

Apparently, Baba who sold this book was Joshua's grandson, who (or whose father) moved from Kaffa to Çufut-Qaleh and brought Joshua's library with him. The collection contains the end of The Guide of the Perplexed, the vocabulary by Samuel ibn Tibbon (1b-14a), and the commentary by al-Tabrizi on Maimonides in its Hebrew translation. ${ }^{77}$ These texts were copied in a Byzantine script, and according to the colophon (14a) written by Haviv ben Elyakim ben Haviv in 1331. They may have been acquired by Joshua ben Nahamu from Rabbanites of Solkhat or Kaffa, who inserted his acrostic (22a). It is noteworthy that the script used by Joshua ben Nahamu (as well as of the Kaffian scribe, Hizkiyah ha-Levi) is of the Byzantine type. We can trace the shaping of the specific Crimean script to the second half of the sixteenth century, apparently modified from a Byzantine script model, in both Karaite and Rabbanite manuscripts.

A collection of Rabbanite texts in Karaite possession (from 1398 to the eighteenth century $)^{78}$ originated in Solkhat. It contains astrological and astronomical texts and tables (partly based on Bar Hiyya's tables). There is an ethical composition by the Provençal scholar Kalonymus ben Kalonymus (1286-1328), entitled 'Even bohan in its Venice edition of 1546 (2a-30a), which was previously, as pointed out in its colophon (2a), in the possession of Zekhariah ben Moses Graziano. $^{79}$

In sixteenth-century Crimea, a new genre of Jewish literature appeared, known as chronography, a description of historical events organized by date. ${ }^{80}$ Interestingly, surviving manuscripts were authored mainly by Karaites. This genre, which flourished until the nineteenth century, recounted historical events - wars, court intrigues, plagues, ethnic strife, taxation, prices, government policy, dreams, exemplary stories, and more. The authors were more focused on the history of nations and less on the affairs of the Rabbanite or Karaite communities. ${ }^{81}$ They would often supplement historical descriptions of events with their own interpretations and opinions. This genre reveals a wealth of data

77. Ibid., 14b-22a. Abu Abdallah Muhammad ibn Abu Bakr al-Tabrizi, a Persian Muslim scholar of the second half of thirteenth century who commented (in Arabic) on the twenty-five propositions appearing at the beginning of the second part of Moses Maimonides's Guide of the Perplexed. Tabrizi's commentary was translated into Hebrew twice, first by Isaac ben Nathan of Cordova (probably in Majorca around 1347), and then by an anonymous translator (Paris, Bibliothèque Nationale, héb., 974). On Tabrizi's commentary, see Harry A. Wolfson, Crescas' Critique of Aristotle: Problems of Aristotle's Physics in Jewish and Arabic Philosophy (Cambridge, MA: Harvard University Press, 1929), index, and its text published by Maurice-Ruben Hayoun, "Moses Maimonides und Muhammad al-Tabrisi," Terumah 5 (1995): 201-45.

78. Russian State Library, Moscow, Ms. Guenzburg 1080.

79. He was possibly a relative of the Jewish Italian bibliophile Abraham Joseph Salomon ben Mordekhai Graciano, who lived in seventeenth-century Modena and possessed a vast Jewish library. See Yael Okun, "Abraham Joseph Salomon Graziano's Manuscripts Library" [in Hebrew] (MA thesis, Hebrew University of Jerusalem, 1991).

80. On the characteristics of this genre, see Akhiezer, Historical Consciousness, 165-89.

81. This phenomenon conformed to the general tendency of Jewish historiography of Europe and the Ottoman Empire following the expulsion from the Iberian Peninsula. See Yosef H. Yerushalmi, Zakhor: Jewish History and Jewish Memory (Seattle: University of Washington Press, 1982), 57-66. 
about the perception of history in the multicultural Crimean environment. The earliest known chronicle (1524) was written by a Karaite author, Samuel ben Nahamu of Kaffa, ${ }^{82}$ who visited Egypt. The author describes the rebellion led by Ahmad Pasha against Suleiman I, and the circumstances of the Jews, both Karaite and Rabbanite, during the uprising. ${ }^{83}$ The only surviving long historical Rabbanite chronicle, Devar sefatayim, deals with the history of the Crimean Khannate from 1681 to $1731,{ }^{84}$ and was written by the abovementioned David ben Eliezer Lekhno of Karasubazar.

A number of early kabbalistic texts circulated in Kaffa, reflecting to some extent the kind of intellectual exchange as well as mystical genres characteristic of the community. The earliest original text from Kaffa was written by the same Karaite chronicler, Samuel ben Nahamu. ${ }^{85}$ He depicts his own dream, in which he experienced a revelation, was transported to the temple of Jerusalem, and saw God. This important text, unprecedented in Karaite literature, deserves a separate study. ${ }^{86}$ The recording of dreams was quite a widespread phenomenon among Karaite authors in the Crimea and eastern Europe, but all the surviving texts date from the seventeenth century.

We find among the Crimean manuscripts the occult text Toldot 'Adam, ${ }^{87}$ on physiognomy, chiromancy, and astrology, which was compiled by Moses ben Eliyahu Galina, a scholar and translator from Candia (fifteenth century). ${ }^{88}$ Another manuscript from the same collection also contains an abridged version of Ibn Sina's Canon of Medicine and the second part of Sefer mafteah ha-refu'ah (The book of the rules of medicine), and the book Akrabadin (Pharmacopeia) ${ }^{89}$ by

82. Samuel ben Nahamu, Various Lists, RNL EVR I, 745.

83. This text was published in Adolf Neubauer, Aus der Petersburger Bibliothek: Beiträge und Documente zur Geschichte des Karäerthums und der karäischen Literatur (Leipzig: Oskar Leiner, 1866), 118 n. XXIa. Neubauer erroneously refers to the author with the Rabbanite name Nahman; the manuscript clearly reads "Nahamu," a typical Karaite name.

84. Devar sefatayim is written in Hebrew and contains fifty-six chapters, only a few of which have been published in Hebrew by Isaak D. Markon, "Devar sefatayim," Devir 2 (1923): 244-73. It is currently being prepared for publication by Aviezer Tutian, of the Ben-Zvi Institute, Jerusalem. Lekhno composed a Hebrew grammar, Mishkan David, see RNL EVR I, 86, and supplements to the prayer book written by R. Moses of Kiev, Hazzaniyah, with an introduction tracing the origins of the Jewish communities in Solkhat and Kaffa.

85. RNL EVR I, 745.

86. I am preparing this text for publication.

87. NLI, B $542\left(8^{\circ} 3970\right)$. The manuscript originated from Gözleve, and according to its owner's record in the eighteenth century (18b) it belonged to Jacob ben Moses Kefeli (from Kaffa). It was copied by a certain Samuel in 1515 (18a). It is unclear if this is the date of copying or that of the first printed edition of this treatise in Istanbul. See Reimund Leicht and Joseph Yahalom, "Sefer zeh Sefer Toledot 'Adam': An Unknown Esoteric Midrash on Genesis 5:1 from the Geonic Period," Ginze Kedem 4 (2008): 9-82.

88. Galina translated the astronomical treatise by Omar ibn Muhammed Mesuman, Sefer mezukkak, from Arabic into Hebrew; an astrological treatise, Mishpat ha-mabbatim; and Sefer ha-goralot, a treatise on geomancy. It was first published in Constantinople, 1515.

89. See NLI B $542\left(8^{\circ} 3969,8^{\circ} 3956\right)$. 


\section{Golda Akhiezer}

Elisha ha-Yevani, ${ }^{90}$ texts copied in the typical late Crimean script. There exists at least one additional manuscript of Toldot 'Adam from the Crimea ${ }^{91}$ that contains, inter alia, spells and other magical practices.

A number of books from the late thirteenth and early fourteenth century were written by the kabbalist Isaiah ben Joseph of Tabriz: 'Ozar ha-hokhmah, Sefer ha-kavod, 'Ez ha-hayim, 'Ez ha-da'at, and Gan 'eden (all these books are gathered under the title Haye nefesh). ${ }^{92}$ Very little data is available on Isaiah of Tabriz. In the introduction to his Sefer ha-kavod, he mentions himself as "Isaiah, who is called a rav, son of the rav, our master Yehosaf al-Tiflisi" (Tiflis/Tbilisi, the capital of Georgia). Tabriz (Iran, eastern Azerbaijan) served several times as the capital of Mongol and Turkic dynasties during the thirteenth and fourteenth centuries. ${ }^{93}$ Until 1295, when Khan Ghazan started a policy of forcible Islamization of Jews, Christians, and others, it was an important Jewish cultural center. ${ }^{94}$ Isaiah's books were possibly brought to the Crimea by Persian Jews.

Special attention should be paid to a Rabbanite collection of texts, especially its copy of Yesod mora' by Ibn Ezra. It was copied, according to its colophon, by the Rabbanite scribe Eliyah ben Jacob Manto in Kaffa in 1489. ${ }^{95}$ This collection also contains twenty-three kabbalistic texts, among them Sefer ha-bahir, an anonymous commentary on the Sefer yezirah (both copied by another scribe), and the Sefer ha-melamed by Abraham Abulafia. These texts were copied by different scribes in Byzantine script. It is unclear whether they originated in the Crimea or Byzantium, since in the fifteenth century the specific Crimean script had not yet taken shape.

Some texts were preserved in Crimean private libraries from the fourteenth or fifteenth centuries until modern times. For example, we find a Karaite sale contract from eighteenth-century Kaffa. ${ }^{96}$ Two of the books sold deal with Kabbalah:

90. Elisha ha-Yevani, a follower of Ibn Rushd and a physician, possibly for senior officials, lived in Ottoman Adrianople in the second half of the fourteenth and first half of the fifteenth centuries. In addition to Greek and Hebrew, he was fluent in Turkish, Persian, and Arabic. In the latter two languages he wrote a commentary on Ibn Rushd, which did not survive. See Efraim Wust, "Elisha ha-Yevani rofe' u-filosof bi-tehilat ha-tekufah ha-'otmanit," Pe'amim 41 (1990): 49-57.

91. IOS A 217, 9a-82a. It begins from the middle of the second chapter and contains a date of 1515 (82a).

92. RNL EVR I, 513-17. The first edition of Isaiah's books was printed by Shlomo Musa from Bukhara. See Sod 'ez ha-da'at (Jerusalem, 1891). It included Sod 'ez ha-da'at, Gan 'eden, Sefer ha-kavod, 'Ozar ha-hokhmah, and Pirke hekhalot.

93. See Walter J. Fischel, “Azarbaijan in Jewish History,” PAAJAR 22 (1953): 4-8.

94. Fischel suggests that Isaiah ben Joseph arrived from Tiflis to Tabriz at the peak of its cultural and economic prosperity, see ibid., 9 .

95. Paris, Bibliotheque Nationale heb. 680, see its colophon 25a. Firkovich tried to rewrite this date to 1289 .

96. RNL EVR I, 443. The first leaf of the collection with the sale contract is unpaginated. The collection itself contains (1) the medieval Arabic work, Sefer ha-tapuah (1a-5b), attributed to Aristotle (translated into Hebrew by Abraham ben Hisdai from Barcelona in the thirteenth century); (2) Penine ha-melizot (6a-18b), selected piyyutim, fables, and ethical sayings by Jewish authors from as early as the thirteenth century (see Gurland, Ginze Yisra' el, pt. 4, pp. 1-34); and (3) Sod ha-sodot, attributed to Aristotle (19a-31b). This latter text (written as a letter from Aristotle to his disciple Alexander the Great 
the Sefer ha-Zohar and the Shoshan sodot, ${ }^{97}$ the latter written by Rabbi Moses, the exile of Kiev (see below). ${ }^{98}$

As we can see, during the seventeenth to nineteenth centuries, Rabbanite and Karaite authors in the Crimea were still copying medieval texts as well as writing original compositions. This period is beyond the scope of this study, although we might note that it was marked by genre diversity and the phenomenon of Rabbanites sharing their books with Karaites, including kabbalistic texts.

\section{Social and Cultural Changes in the Early Sixteenth Century}

The first attempt to unify various Rabbanite congregations from different lands was undertaken only at the beginning of the sixteenth century, by the Lithuanian scholar R. Moses ben Jacob ha-Goleh (the exile) from Kiev (1449-1520), an author of books on astronomy, Bible exegesis, and Kabbalah. From 1478 to 1480, R. Moses split his time between Adrianople and Istanbul, where he studied Torah and Kabbalah. ${ }^{99}$ He studied astronomy under the guidance of the Karaite scholar Eliyahu Bashyachi. On his return to Lithuania, R. Moses conducted debates on Halakhah with local Karaites, but unlike most Rabbanite scholars in Istanbul, and especially in eastern Europe, ${ }^{100}$ he pursued an exceptionally integrative agenda: he tried to convince the Karaites of the Rabbanite way of observance of the Torah. ${ }^{101}$ In 1506, R. Moses was taken captive by Tatars who invaded Lithuania, and was brought to Solkhat, where he was ransomed by the

with discussion of ethics, physiognomy, astrology, alchemy, medicine, etc.) was translated from Arabic into Hebrew in the thirteenth century. See W. F. Ryan and Charles B. Schmitt, Pseudo-Aristotle, the "Secret of Secrets": Sources and Influences (London: Warburg Institute, University of London, 1982).

97. The 193 final paragraphs of this book are a commentary on the Sefer yezirah. They were published under the title 'Ozar ha-Shem in Koretz, 1779. The remaining part was also published in Koretz in 1784 . The other books on Kabbalah by R. Moses, his commentary on Pentateuch, She are zedek, and Sefirot 'elyonot were lost.

98. The three other books mentioned in the same sale contract are Me'il Shmu' $\mathrm{Cl}$ by the Karaite author, Samuel ben Joseph Kali, of the eighteenth century; the commentary on Sefer ha-mivhar, 'Emunot ve-hasagot (possibly 'Emunot ve-de 'ot by Sa'adyah Gaon); and the ethical treatise, Behinot 'olam (Examination of the world) by Yedaiah ben Abraham Bedersi of Provence (c. 1270-1340).

99. The writings of R. Moses attest to the adoption of a specific doctrine of Kabbalah common in Byzantium. See Moshe Idel, "The Kabbalah in Byzantium: Preliminary Remarks," in Jews in Byzantium: Dialectics of Minority and Majority Cultures, ed. Robert Bonfil, Oded Irshai, Guy G. Stroumsa, and Rina Talgam (Leiden: Brill, 2012), 693-7.

100. Mere decades later, the most influential Sephardic and Ashkenazic halakhic decisors, Joseph Karo and Moses Isserles (Rama'), ruled that intermarriage with Karaites was forbidden. See Shulhan 'arukh, 'Even ha-'ezer, § 4. However, other rabbis in the Ottoman Empire and Egypt permitted such marriages. See Simcha Assaf, "Le-toledot ha-Kara'im be-'arzot ha-mizrạ," in Be-'ohole Ya'akov: Essays on the Cultural Life of the Jews in the Middle Ages, ed. Simcha Assaf (Jerusalem: Sifriyat Ya'akov Mikha'el, 1943), 182-90.

101. He wrote his 240 polemical objections (hassagot) against Karaite law in the margins of the book Gan 'eden by Aaron ben Eliyahu of Nicomedia. This book (as well as all the property of R. Moses and his children) was plundered by Tatars during their invasion of Kiev and brought to the Crimea. It was discovered in 1487 by the Karaite community leader Joseph ben Mordekhai of Troki, the fierce 


\section{Golda Akhiezer}

common effort of the Karaite and Rabbanite communities. According to the colophon in his book, 'Ozar nehmad (Nice treasure), ${ }^{102}$ a commentary on Ibn Ezra (completed in Solkhat in 1515), he lived in Solkhat for about ten years. He spent the last five years of his life in Kaffa as the leader of the Rabbanite community. In order to unify the various Rabbanite communities in Kaffa, R. Moses created a uniform ritual, known as the Kaffa Rite (Mahzor minhag Kaffa). It includes the siddur, the prayers for holidays, and eighteen rulings concerning marriage, divorce, property issues, prayer, and more. ${ }^{103}$ One of the most important Jewish collections of liturgical poems, the Kaffa Rite contains, in its final versions of both the printed siddur and the mahzor, ${ }^{104}$ about 315 piyyutim. It reflects stages and tendencies in the history of liturgy of the Crimean Rabbanites, and reveals the interaction between quite different communities from early modern times until the end of the seventeenth century. ${ }^{105}$ Before the appearance of the Kaffa Rite, a considerable number of local Jews used the Minhag Romanyah (Romaniot rite), common in Byzantium and similar to the Italian early Roman rite. ${ }^{106} \mathrm{R}$. Moses used Minhag Romanyah as a basis for unity, and his choice apparently reflects the prevailing impact of Byzantine Jews on Kaffa. In addition, R. Moses added the piyyutim from different communities, including those of Persian Jews, to the Kaffa Rite. ${ }^{107}$ Mahzor Kaffa continued to be a dynamic collection, incorporating additional piyyutim until the end of the seventeenth century. At first it included piyyutim from local scholars, such as R. Moses, Abraham Kirimi, R. Elyakim, and Isaac Handali, and later incorporated piyyutim from Israel Najara, Isaac Luria, Moses Zacut, and others.

Data on non-Jewish cultural life in Solkhat provides the background for our understanding of the intensive intellectual activity in the area. Indeed, tracing the origins of non-Jewish communities in Solkhat could provide at least a partial solution to the mystery of the origins of the Karaites there. The case study of the

opponent of R. Moses, when, en route to Istanbul, passing through Kaffa, he redeemed this book from the Tatars. See Mann, Texts and Studies, 1170-71, doc. 117a; Tsinberg, "Avraam Krymskii," 104.

102. SP IOS C 112. On the Kaffa Rite see Bernstein, "Ha-mahzor ke-minhag Kaffa," 451-538.

103. The rulings of R. Moses were published anonymously by Shmuel J. Finn, "Hakhme Israel be-Krim," Ha-karmel (October 28, 1862): 101-2.

104. The Siddur Kaffa was published only in the eighteenth century by the Karaites in ÇufutQaleh (1735) and in Mezhirov (1793). See Isaak D. Markon, "Ma'amar 'al-'odot Mahzor Kaffa," in Zikaron le-'Avraham 'Eliyahu: Kevuzat ma'amarim be-hokhmat Yisra'el, ed. David Ginzburg and Isaak D. Markon, vol. 2 (Jerusalem: n.p., 1969), 450 n. 4.

105. See a list of its piyyutim and their authors in ibid., 455-69.

106. See Daniel Goldschmidt, Mehkare tefillah u-fiyyut (Jerusalem: Magnes, 1980), 154.

107. According to Bernstein, "Ha-mahzor ke-minhag Kaffa," 474-75, R. Moses added these piyyutim in spite of their doubtful literary quality, in order to prevent the attraction of Persian Jews, ignored by other communities, to the Karaites, who ostensibly tried to recruit them. However, this last claim is not supported by sources. Moreover, in light of the integrative tendencies of R. Moses even towards Karaites, his aspiration to unify the Rabbanite communities regardless of their specific customs and beliefs seems quite plausible. 
Armenian community, which spoke the same Turkic-Qıpçaq language as the Karaites and also established new communities in eastern Europe, helps us to track similar processes in the Karaite community. The more abundant surviving Armenian manuscripts, and their better condition, enable us to trace Karaite origins in Podolia and Galicia (from Solkhat), the process of turning their spoken TurkicQipçaq into a written language, and the direction of their textual transition.

The selected Crimean manuscripts presented above attest that Solkhat and Kaffa, beyond being important Jewish scholarly centers, were, to a large extent, part of the Byzantine Jewish cultural orbit. The Romaniot ritual tradition was used as a basis of integration for the different Crimean Rabbanite communities. The local Karaite communities also maintained constant connections with the Byzantine Karaite center.

The great diversity of the Crimean communities made them a special cultural entity in the Black Sea region. Notwithstanding the differences and frictions, their prevailing tendency was integrative rather than separatist. In addition to the unification of the diverse Rabbanite communities, a tendency towards rapprochement between Karaites and Rabbanites was apparent. Karaites studied under Rabbanite teachers (as in Byzantium), Rabbanite children were taught in Karaite study halls, Rabbanite liturgical poems were adopted by Karaites in their prayer book, and Karaites made use of all categories of Rabbanite literature-from Halakhah to Kabbalah.

The exchange of Rabbanite and Karaite original and copied texts from various fields, over the centuries, between the Crimean and other Jewish centers, reveals set patterns of study and displays the main vectors of circulation of knowledge common to the Jewish world from the Middle Ages to early modern times. 